\title{
THE EFFECTIVENESS OF ARCHIVING SIMULATION VIDEO IN VOCATIONAL HIGH SCHOOL
}

\author{
Wisnu Wibisono \\ Master of Economic Education, Sebelas Maret University Surakarta \\ wibiwisnu@yahoo.com \\ Baedowi \\ Master of Economic Education, Sebelas Maret University Surakarta \\ baedowi@staff.uns.ac.id \\ Cicilia Dyah Sulistyaningrum Indrawati \\ Office Administration Education, Surakarta Sebelas Maret University \\ cicilidyah@staff.uns.ac.id
}

\begin{abstract}
This study was a research and development. The media developed employed Ulead software with video player application. The development stage was conducted using Hannafin and Peck's development and implementation model. The instruments employed in this research were questionnaire and test. The results of interview and observation were analyzed using descriptive qualitative method, while questionnaire and test using descriptive quantitative one. Considering the result of analysis on the effectiveness of archiving simulation video using IBM SPSS 20 software with $t$-test formula, it could be found that the t-statistic value of posttest was 4.16 for both experiment and control classes with $t$-table score of 2.00 ; thus, $t_{\text {statistic }}>t_{\text {table }}$ meaning that the improvement of learning outcome value for experiment class was better than that for control class. The learning outcome for experiment class showed the mean post-test score of 80.28 while that for control class of 70.56. The difference of mean posttest score between experiment and control classes was 9.72 point. The conclusion of research was that the archiving simulation video was feasible and effective to be used to improve the students' learning outcome.
\end{abstract}

Keywords: simulation video, archiving, students' competency 


\section{INTRODUCTION}

In globalization era, human being is required to keep evolving following the time development. The foundation to keep following the time development is education world. Thus, there should be some attempts of improving the quality of education. The important aspects affecting the quality of education are, among others, learning model and learning media used. Technology development is one factor contributing to students' learning behavior. Students unconsciously have been a part of digital native generation living in digital age in which they can get information easily and other facilities through digital media.

The development of Science and Technology highly affects education realm in Indonesia. It can be seen from learning infrastructure and learning media used by a teacher in delivering material to the students. Technology advance requires a teacher, as an educator, to keep innovating in creating learning media that can support the students' understanding in learning the lesson material, both theoretically and practically. Learning media is everything that can be used to stimulate thinking, feeling, attention and ability or skill of learners, thereby encouraging the effective learning process to occur. In addition to aiming to facilitate the delivery of material from teacher to students, the use of learning media can also improve the students' interest and willingness in a subject. Therefore, the position of learning media in education world is very desirable.

Learning is not an end, but a process of achieving the end (objective) (Hamalik, 2011, p. 29). The use of learning media in learning process is expected to affect the learning the students encounter and the objective to be achieved in the learning itself.

An appropriate learning media is expected to improve the students' skill. The appropriate learning emphasizes on learning by doing as the attempt of practicing the student competency. Such the competency is expected to improve students' problem solving and critical thinking abilities in the learning activity. In the learning activity, competency can be applied using scientific approach, for example, observing, questioning, presenting, reasoning, and trying. Competency can also be optimized by applying student-centered learning; therefore the students will solve the problem independently in the learning process. Such the condition is consistent with the revised 2013 Curriculum applied to education today.

Competency is the main point to which the students should pay their attention. Student competency highly affects the competition for job realm. This competency includes skill, knowledge and attitude of students. Skill is required in job realm to do an employee's job. An employee needs knowledge to equip $\mathrm{him} / \mathrm{her}$ in working. The students of Vocational Middle School (Sekolah Menengah Kejuruan, thereafter called SMK) need prominent competency. Vocational High School (SMK) prepares the ready-to-work workers; therefore, the learning process can equip the students with skill competency learnt and adjusted with the problem in job realm. The competency of SMK students should be improved, recalling the high unemployment rate in SMK graduates.

There are some skill packages in Vocational Middle School: accounting, marketing, network computer technique, and office administration. This research discusses office administration skill program.

The office Administration skill package contains archiving subject. Archiving subject consists of two important components: document management and archive management. Archive management contains archiving material, while mail/document management contains the management of exiting and incoming mail. However, the limited number of effective learning media makes the students having no maximum skill as expected. Because the students have inadequate competency, the students are less ready for work realm.

Learning media is an important part in learning at school because through learning media teacher can distribute knowledge more easily to the students and the students will be helped with the presence of media in learning process. Jong, Specht, \& Koper (2008) suggest that learning media should be improved to follow technology development, media should adapt to the framework in the learning process to achieve the learning objective. Technology development results in digital technology in learning process. One of digital technologies existing is simulation video. 
Riyana (2007) say that simulation video is a medium displaying audio and visual presentation containing learning messages including concept, principle, procedure, knowledge application theory to help understanding a learning material. Simulation video is presented in the form of video series that has been processed into an attractive appearance to be learning media.

Considering the result of observation, the students' maximum skill is due to teachers still using conventional learning method and teaching based on theory only. Thus, the students' competency is less maximal because the students are focused on theory only, without the example of practice. This result is confirmed with the result of interview with teachers assuming archiving subject stating that the students' competency in archiving subject has not been maximal in managing mail/document due to low intensity of practice and inadequate example of practice given, so that the students understand material less maximally in practice material.

In the presence of practical and simulation sample in simulation media, the students are expected to observe and to elaborate theory better. Such the condition is in line with Murtono \& Miskiyah (2014) that finding that the simulation learning gets positive response from the student. Simulation is expected to improve skill. This opinion is also consistent with the journal written by Berk (2009) that discussing the potential of video to be an appropriate media in utilizing the students' intellectuality. This method is considered as appropriate to the present generation. The students re interested in observing the video displayed.

The goals of research is to find out the effectiveness of simulation video learning media to improve the students' competency.

Learning media is a learning aid. Using an appropriate learning media, the learning is expected to be effective. In information and technology development, the technology and information-based learning media is required. Learning process is expected to be more effective due to the appropriate information technology-based learning media advance. One of information technology-based learning media that can be used is digital media. Using digital media, the learning process can be effective. Therefore, the author chooses digital media, simulation media, to deal with the problem found. The development of simulation-based video can be beneficial to students, teachers and schools. This research is beneficial to the students because it can be the learning source for them and can improve their skills. It is beneficial to teachers as well, because it can improve teachers' skill and performance in using digital learning source in the classroom. Additionally, it is beneficial to the schools because it can improve the quality of learning in schools and can be input to the schools in relation to the use of simulation video use that can improve the students' skill.

\section{METHOD}

The research conducted was research and development type. Borg and Gall (Sugiyono, 2011, p. 4) state that "Research and Development or R\&D is the research method employed to develop or to validate the products used in learning education".

Research and Development are different from education research as the objective of development is to produce a product based on finding in the field test, and then when the product developed has some weakness, it will be revised. The product of development can be used as learning media so that it can improve the students' learning outcome in Office Administration Productive Skill area in SMK Negeri 1 Surakarta.

The development model referred to in research was Hannafin and Peck's development design. Hanafin and Peck's model is one of many product-oriented learning design models. The product-oriented model is the learning design model to produce a product, usually learning media (Tegeh, Jampel, \& Pudjawan, 2014, p. 1). The product yielded in this research was archiving simulation video. Hanafin and Peck (Tegeh et al., 2014, p. 1) say that learning design model consists of three stages.

The first phase of Hannafin and Peck's model is need analysis. This phase is needed to identify the needs in developing a learning media within which the objective of learning media, knowledge and competency needed by targeted group, equipment and learning media needed are set out. After all of needs are identified, Hannafin and Peck emphasize on 
assessing the result (product) before continuing the development to design phase. The second phase of Hannafin and Peck's model is the design one. In this phase, information from analysis phase is transferred into document form that will be the objective of learning media development. This design phase aims to identify and to document the best rule (norm) to achieve the objective of media development. The third phase of Hannafin and Peck's model is development and implementation phase. Hannafin and Peck state that the activity conducted in this phase results in flowchart and formative and summative evaluations.

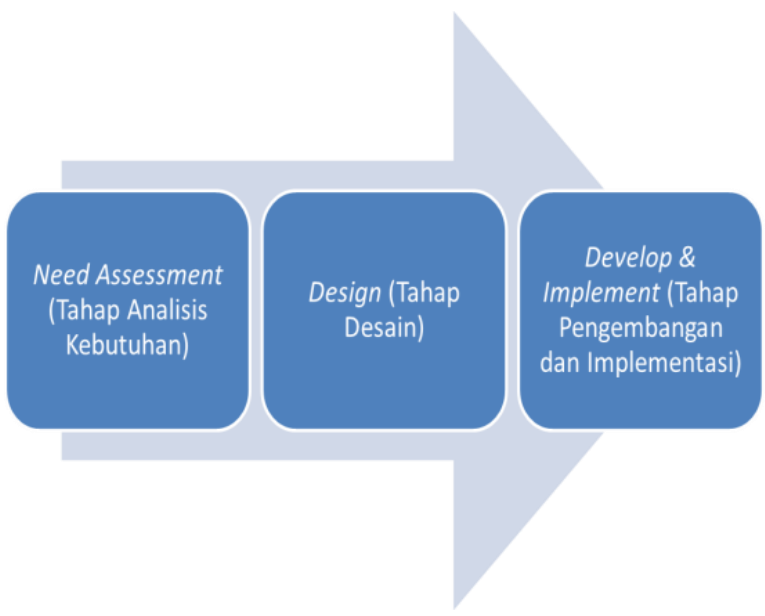

Figure 1. Learning Design Model

\section{Data Collection}

There were some instruments used to collect data in this research:

\section{Observation}

Observation was used to collect data and to record important things in teachinglearning activity and to see the students in the process of trialing the product developed. In this case, observation was conducted using direct observation, thereby confirming the information obtained as the attempt of dealing with the problems occurring in the learning.

\section{Interview}

Interview was used in initial stage of preliminary study to find out the prior condition of learning process in the research location. Interview was very effective to be used as the supporting data for the author. In this case, the result of interview included response, critique, recommendation and input relevant to the product developed, before being used.

\section{Questionnaire}

The questionnaire was used during evaluation before and after product trial by material and media experts. Meanwhile, the questionnaire for the students was used to find out the students' response and teacher on the media developed. In this case, questionnaire as an efficient technique of collecting data when the author finds out surely the variable to be measured and understands what the respondents expects.

\section{Test}

Test was conducted with the students after using the product developed, learning media in the learning process. In this case, the result of test was used to find out the effectiveness of media developed by the author.

\section{Documentation}

This documentation was used to collect the data from research location, student name, teacher name and some guidelines in preparing the material used in learning media. The document was used as the evidence to support the quality of data and evidence of data validity obtained.

\section{RESULT AND DISCUSSION}

The development of archiving simulation video conducted by the author employed Hannafin and Peck's product development's model. The procedure of developing archiving simulation video consists of three stages: need assessment, design, and develop and implement.

\section{Need Assessment}

Need assessment (need analysis) is the measure taken before the development process in the media prepared, so that the need should be identified in following up the media development planned in the beginning of design. The objective of analysis is to obtain data and to support information in developing media so that the media produced will be consistent with the media users' need later. This need analysis is conducted by the author 
during observation and interview in the research.

Considering the result of observation conducted, the author obtained the following data.

\section{Material Analysis}

The analysis was conducted using qualitative method in this stage, the result of observation on archiving class. The result of observation shows that in delivering the learning material, the teacher still needs appropriate method to deliver the learning material to the students. This constraint will contribute to the achievement of learning objective leading to the student competency later.

The subject is archiving one with basic competency of mail handling. Archiving in End-Semester Test is still low and has not achieved the minimum competency achievement. Archiving simulation video media is developed by adjusting materials delivered to the students, and seeing competency and learning outcome the students should achieve in learning process. The constraints found in this class will affect the achievement of learning objective and the effectiveness of students' learning outcome.

In anticipating this, a new learning media in the form of Archiving Simulation video is required to stimulate the students' imagination and to support the students' learning and creativity in the learning process.

\section{Media Analysis}

Media analysis was conducted using qualitative method, the result of interview carried out with corresponding teachers. In this stage, the author acquires information from corresponding teachers wishing that the learning media developed in the form of archiving simulation video can be the learning material for students in the classroom and at home for independent learning.

Considering the media analysis stage, the author obtained information from teacher assuming archiving subject, stating that the students have not had poor skill of managing mail/document in archiving subject due to practice intensity and limited example of practice given, so that in practice material, the students have not understood the material maximally.

In developing learning media, an analysis should be conducted on the learning objective to be achieved and on the existing media. The content of learning media developed refers to the enacted curriculum. In media analysis, the author acquires information that there has been no simulation video supporting the learning in the class. In this case, archiving teacher still teaches using conventional method; as a result, the subject delivered by teacher cannot be received well by students, because the achieving learning is based on practice. Teacher has not found yet the appropriate method to deliver archiving material, so that the teacher cannot give visual example maximally.

The result of interview with teachers reveals the representations related to learning activity as follows: (1) learning still uses lecturing method, (2) learning set the teachers have has been fairly complete including syllabus, RPP (learning implementation plan) and LKS (student worksheet), (3) infrastructure in the school has been adequate, (4) the students' learning outcome has not been optimal, as indicated with the successful passing in the result of even semester test.

\section{User Analysis}

The author develops archiving simulation video in archiving subject so that it can be used by teacher in delivering material in the class. Teacher can operate laptop LCD and sound system in the class to support the learning thereby facilitating the operation of Archiving Simulation Video. Archiving simulation video is expected to change the students' perspective on the boring and saturating archiving subject, and they are expected to be more interested in learning archiving material.

The result of observation conducted in SMK Negeri 1 Karanganyar shows that there are adequate infrastructures to support the learning process. With good supporting infrastructure, it is possible to apply archiving simulation video in SMK Negeri 1 Karanganyar.

Considering the need analysis conducted, it can be seen that teachers find difficulty 
in delivering the archiving learning material because it is based on practice rather than on theory only. In this case, the teachers find difficulty in creating a creative innovative learning media that can trigger the students' learning spirit and motivation thereby improving their competency in archiving subject. This development of simulation video is supported with adequate infrastructures such as LCD and laptop usable to the students as the users of simulation video. This archiving simulation video can be used during learning in the classroom or independently out of class so that the presence of archiving simulation is expected to support the learning activity and the students can master the material more easily and better so that their competency improves.

\section{Design stage}

The development of draft product in simulation video is based on the result of observation in the beginning step of preparing to produce a learning media, need analysis activity. This stage includes some steps:

\section{Determining the Basic Competency}

This basic competency is determined based on the syllabus of archiving subject in SMK Negeri 1 Karanganyar. In determining the Basic Competency to be developed in simulation video production, the author discusses with archiving subject teacher of the $10^{\text {th }}$ grade of office administration productive skill area.

Table 1. Basic Competency Developed

\begin{tabular}{ll}
\hline Basic Competency & Basic Material \\
\hline 3.16 Explaining the & The management of \\
management of & incoming and exiting \\
exiting and incoming & mails \\
mails (Agenda & - Incoming mail \\
System, Control & management using \\
Card System) & Agenda Book System \\
& - Exiting mail \\
4.10 Practicing the & management using \\
procedure of & Control Card system \\
managing exiting & - Exiting mail \\
and incoming mails & management using \\
(Agenda System, & Agenda Book System \\
Control Card & - Incoming mail \\
System) & management using \\
& Control Card System \\
\hline
\end{tabular}

(Source: Archiving Syllabus)

\section{Selecting and collecting material}

The author selects and collects the material in the form of text, and supporting video that can make the media communicative, thereby attracting the students' attention in the active and student-centered learning process.

\section{Material Map Design}

The material map is a part or flow of competency in archiving learning material. The material map preparation is conducted by means of elaborating in detailed the material in some subject matters. The material used is adapted to the basic competency organized in developing the learning media.

\section{Outline Design of Media Content}

Outline design of media content is is the instruction that can be guidelines for text writing. Outline design is conducted in need analysis stage. Outline design contains the specifics of media to be included into archiving simulation video. This outline contains Basic Competency. The design of appearance is adjusted with the archiving learning material so that the compatibility of material content to learning objective can be achieved. The organization of outline design is carried out based on the Archiving Syllabus and RPP for the 10th grade of SMK Negeri 1 Karanganyar.

\section{Preparing Storyboard}

Design and storyboard developed are consulted first with material expert, media expert and linguist. Revision will be done when the design has not been consistent. When the design has been considered as good, the media development process would increases to the next stage, development (product development) stage.

\section{Appearance Design}

The design of appearance in his archiving simulation video learning media product employs Ulead software. This ulead software can design video, including text, figure, animation, and audio corresponding to the material displayed.

This development of archiving simulation video produces media by means of converting the material into simulation video or practical example of managing mail/document 
interactively. The end product of production activity is a series of texts, video, audio, and picture ready to be submitted to editor. The production process is followed with postproduction activity. In post-production stage, best text, video, audio and picture are selected. The components of archiving simulation video are synchronized and harmonized so that the learning media is ready for trial with experts as reviewer and students as trial subject in this research.

The use of archiving simulation video media is conducted using individual learning model. In this case, the learning is conducted in the classroom where some supporting media such as laptop, LCD, and sound system are available.

This development of archiving simulation video produces a media by means of converting the material into practical simulation in the form of interactive archiving simulation video.

\section{Development and Implementation Stage}

This development of simulation video starts with preparing text, audio, and video necessary in the learning material, the process of producing archiving simulation video is conducted by organizing the material corresponding to the syllabus of archiving subject using Ulead as the main software. This teaching material is organized using ulead software consisting of text, audio and video thereby attracting the students' attention in learning process and facilitating the students in understanding the learning material existing. In this stage, editing and revision should be done on the archiving simulation video used in archiving learning process.

The development of simulation video media starts with preparing text, picture, audio and video needed in learning material. The process of developing archiving simulation video starts with organizing material corresponding to the syllabus of archiving subject. Thereafter, the material is simulated by simulation team designated by the author to help this media development process. The result of simulation conducted is recorded and then processed using video ulead application. In addition to simulation result, texts and supporting audio are prepared as well to support the simulation video media. This video processing consists of text, audio and video thereby attracting the students' interest in attending the learning and facilitating the students to have an understanding on the learning material. After archiving simulation video media is ready to use to help deliver material to students, supporting application is required to play the video, media player classing or other video player applications.

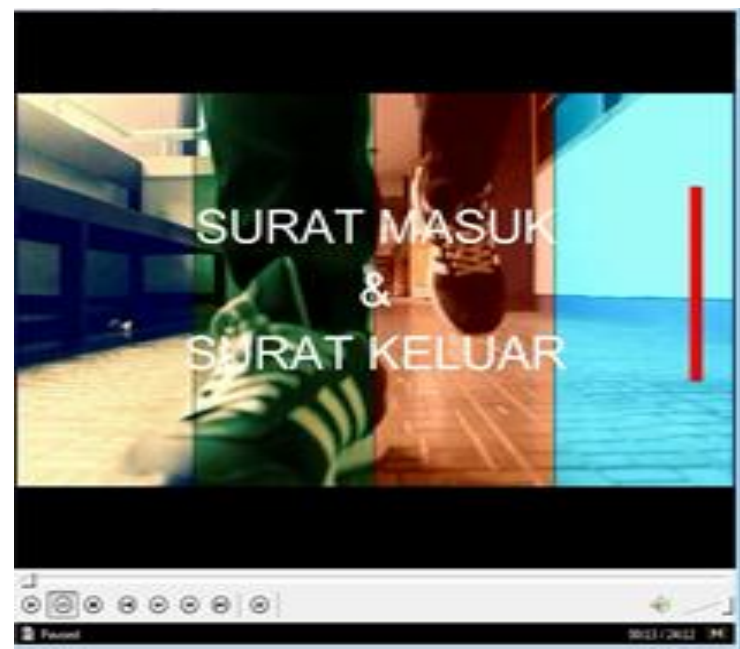

Figure 2. Appearance of Simulation Video Design

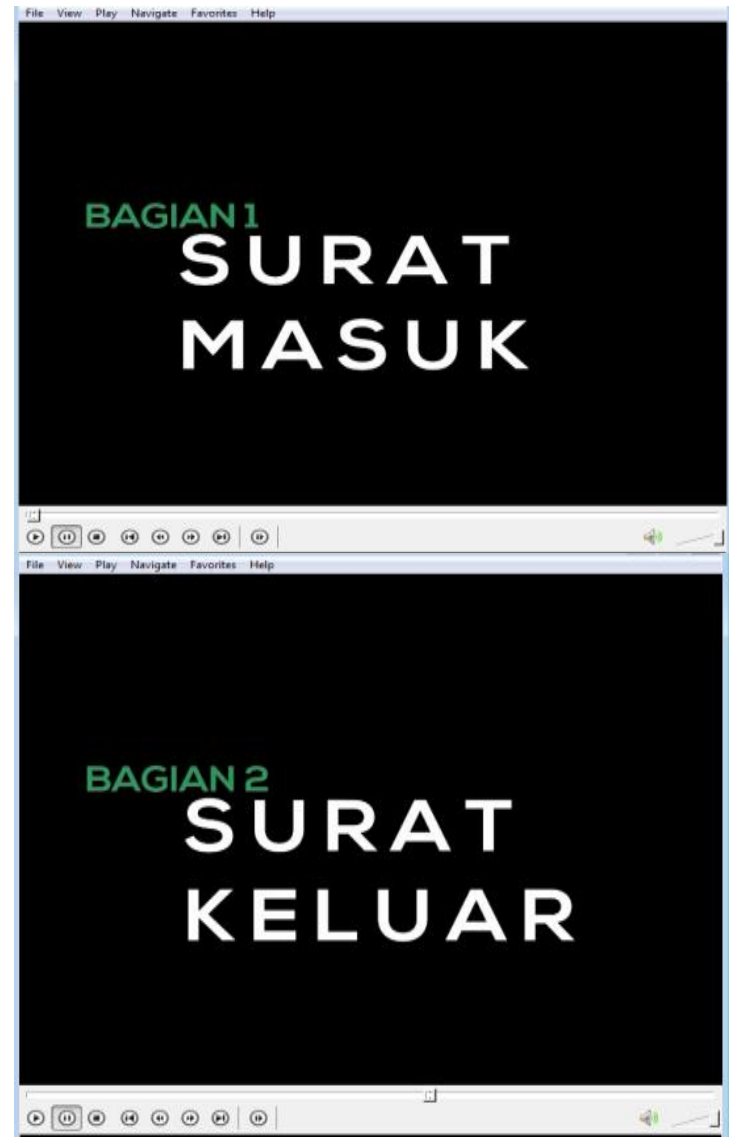

Figure 3. Main Menu of Simulation Video 

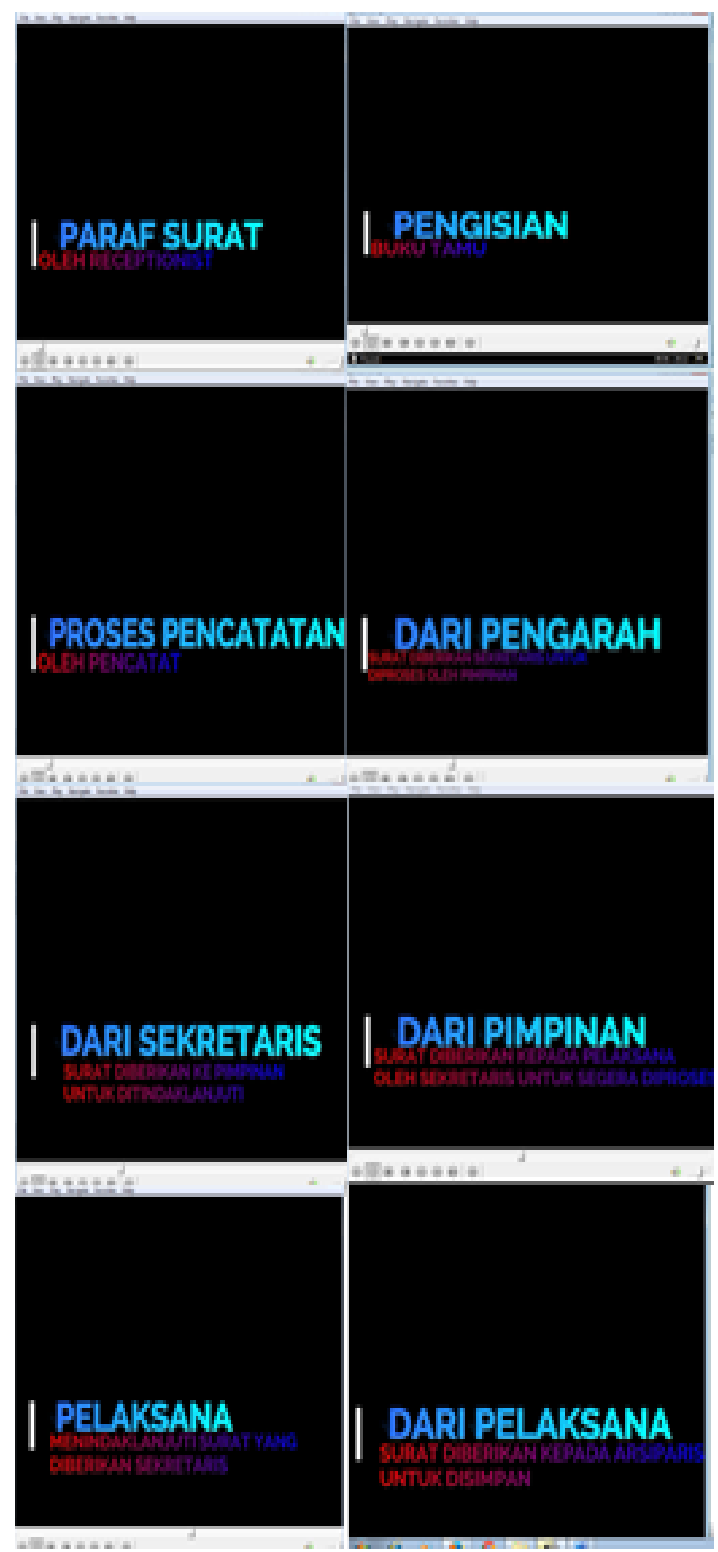

Figure 4. Map Concept in Coming Mail

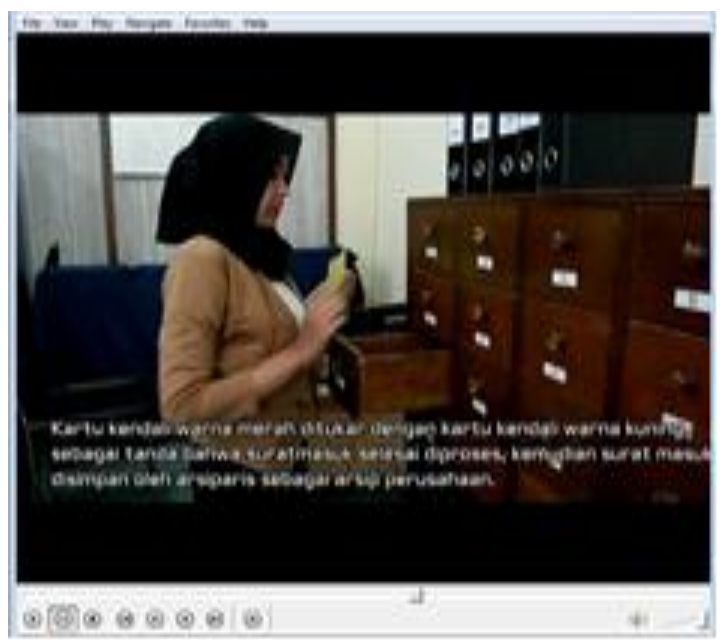

Figure 5. Learning Material
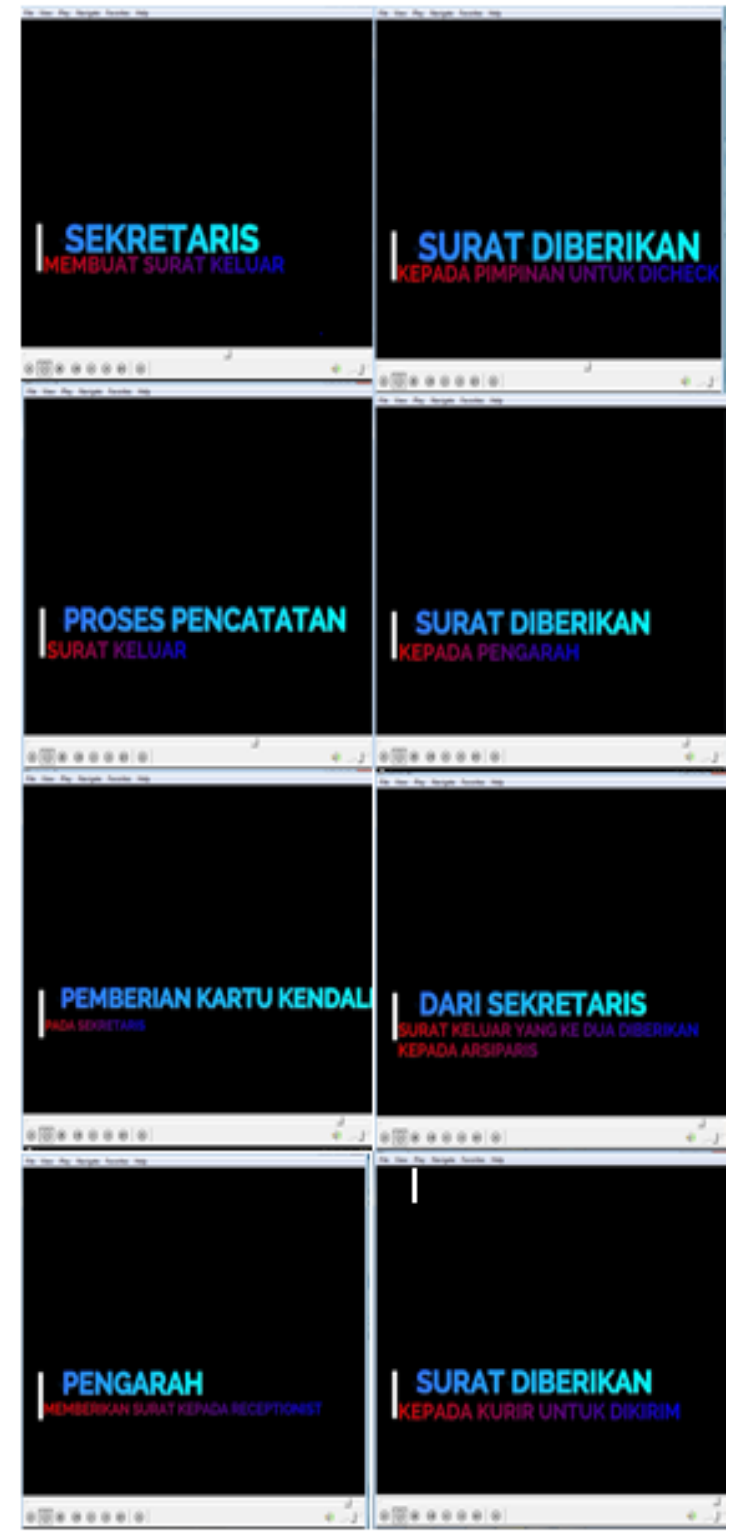

Figure 6. Map concept Out Mail

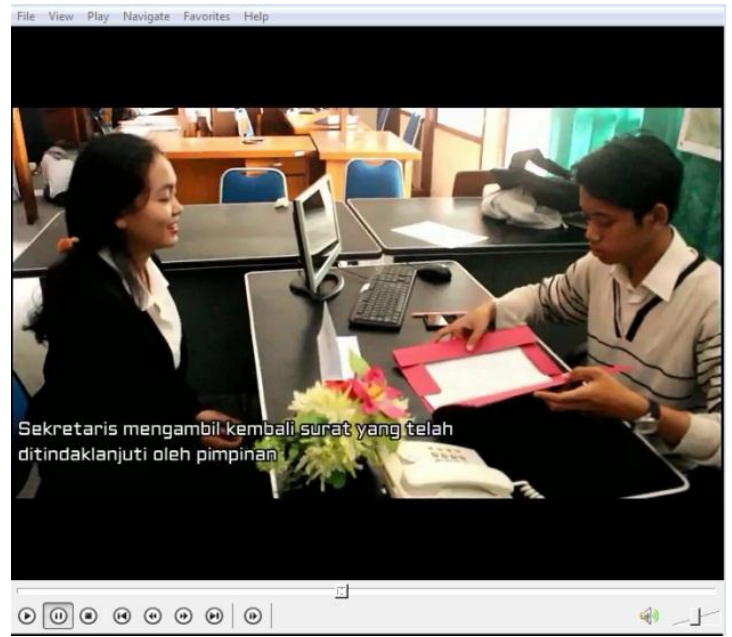

Figure 7. Simulation Example 
Considering the product trial validated by media and material expert, this media developed is feasible to use in the learning process.

Based on the result of t-test (independent sample test) during pretest between experiment and control classes, it can be found that the significance value of $\mathrm{t}$-test is 0.190 . It is higher than 0.05 , meaning that $\mathrm{H}_{0}$ is not supported and $\mathrm{t}$ statistic is $2.394<\mathrm{t}$ table (2.00). It indicates that there is no significant difference of mean learning outcome between students in experiment and those in control classes in the pretest; then the experiment class was treated using archiving simulation video, while the control was not. It means that the experiment class is treated with archiving simulation video, while the control one is not.

The result of posttest shows the mean score of 80.28 for experiment class, and 70.56 for the control class. It indicates that the score of experiment class is higher than that of control class. The score of experiment class before using Archiving simulation video is 62.92 and that after is 80.28. This result indicates that archiving simulation video improves the students' learning outcome effectively in archiving subject.

The result of t-test (independent sample test) in experiment and control class shows that the significance value of $t$-test is 0.014 . It is less than 0.05 , meaning that $\mathrm{H} 1$ is supported, and t statistic is $4.159>\mathrm{t}$ table (2.00). It indicates that there is a significant difference of mean learning outcome between students in experiment and those in control classes. This result shows that experiment class has better learning outcome than the control class, meaning that experiment class using archiving simulation video obtains the mean score of posttest higher than the control class not using it.

Considering the learning outcome, it can be found that the experiment class has better learning outcome than the control class because the experiment class is treated with archiving simulation video. It can be concluded that the effectiveness of archiving simulation video media is very good; the students formerly less enthusiastic become enthusiastic with learning process. Simulation video media is based on practice as well, so that the students understand the material delivered more easily as the mail/document management material is a practical one. In addition, archiving simulation video media motivates the students to learn thereby improving their learning interest impacting on the learning competency the students gain in the learning process.

The characteristics of archiving simulation video-based file are usable and flexible because it can be included into users' laptop, smartphone, and gadget setting thereby it is portable and usable wherever and whenever. That is why archiving simulation video is acceptable to its users. Simulation video is usable and its use is desirable particularly to write assignment or to work on a project. It can indirectly improve the effectiveness of learning (Ismail \& Ngah, 2005).

The use of simulation video media is fairly easy, just like playing video on laptop or cellular phone using video player application help such as windows media player, media player classic, Gom player or other applications. With such the condition of simulation video media, the media will be used appropriately in learning process. It is consistent with the journal written by Berk (2009) that discussing the potential of video to be an appropriate media in utilizing the students' intellectuality. This method is considered as appropriate to the present generation. The students are interested in observing the video displayed.

Effectiveness is an ability of selecting the appropriate objective or instrument to achieve the intended objective. Handoko (2003, p. 7) states that effectiveness can be defined as the successful level achieved from a certain way or attempt corresponding to the objective to be achieved. It is in line with (Trianto, 2010, p. 24) arguing that learning effectiveness is the benefit obtained from the implementation of teaching-learning activity.

\section{CONCLUSION}

Archiving simulation video improves the students' competency effectively. The effectiveness of archiving simulation video builds on the improvement of student competency value. The increase in the mean competency score shows that archiving simulation video results in a very effective and positive change in the students. The effectiveness of archiving simulation video is 
confirmed with the result of pretest obtaining the mean score of 62.92 and pretest obtaining mean score of 80.28 (increasing significantly) in the field test. The mean score of student competency increasing in archiving subject before (pretest) and after (posttest) using archiving simulation video shows that the archiving simulation video effectively improves the students' competency in archiving subject. The use of archiving simulation video improves the students' competency effectively, supported with significance value of 0.014 $<0.05$ in the effectiveness on experiment and control classes showing the very significant difference ( 80.28 for experiment and 70.56 for control classes). Considering the mean score of competency in the posttest, it can be concluded that the score of experiment class is better than control class value.

The development of archiving simulation video shows that archiving simulation video improves the students' competency effectively in archiving subject, particularly in basic competency of mail/document management. In the presence of archiving simulation video can attract the students in attending learning process because archiving simulation video is designed with attractive, usable and learnable appearance so that the students can understand the information within it.

\section{To Headmasters}

The headmasters should encourage the teachers to create an innovative and creative learning media that can attract the students' attention. It can be done through holding training on learning media development and workshop on learning media, thereby expectedly improving the quality of school and producing the more competitive graduates.

\section{To Teachers}

Before using simulation video learning media, teachers should copy archiving simulation video first and then transfer it into cellular phone or laptop used as an aid to play simulation video. Thereafter, they can prepare video player application in cellular phone or laptop. This application is expected to read the format of simulation video prepared. Then, teachers can play the video using the video player application prepared. Teachers can set the time appropriately to deliver the material corresponding to the existing syllabus, so that the material can be delivered well and learning media can serve to improve the competency of students.

\section{To other Developers}

This research is still limited to one school only; therefore further researches should be conducted on many more schools. Besides, the archiving simulation video developed has not involved all basic competencies the students should achieve in one semester, so that the development of other subject matters is required.

\section{REFERENCES}

Berk, R. A. (2009). Multimedia teaching with video clips: TV, movies, YouTube, and $\mathrm{mtvU}$ in the college classroom. International Journal of Technology in Teaching and Learning, 5(1), 1-21. Retrieved from http://www.ronberk.com/articles/2009_v ideo.pdf

Hamalik, O. (2011). Proses belajar mengajar. Jakarta: Bumi Aksara.

Handoko, T. H. (2003). Manajemen personalia dan sumberdaya manusia. Yogyakarta: BPFE.

Ismail, R., \& Ngah, Z. A. (2005). The pattern of e-book use amongst undergraduates in malaysia: A case of to know is to use. Malaysian Journal of Library \& Information Science, 10(2), 1-23. Retrieved from http://ejum.fsktm.um.edu.my/ArticleInfo rmation.aspx?ArticleID=327

Jong, T. de, Specht, M., \& Koper, R. (2008). Contextualised media for learning. Journal of Educational Technology \& Society, 11(2), 41-53. Retrieved from http://www.ifets.info/journals/11_2/5.pd f

Murtono, \& Miskiyah, E. (2014). Pengembangan instrumen evaluasi dengan teknik simulasi sebagai asesmen alternatif dalam pembelajaran fisika materi mekanika fluida SMA kelas XI. Jurnal Inovasi Dan Pembelajaran Fisika, 1(1), 1-11. Retrieved from 
http://ejournal.unsri.ac.id/index.php/jipf/ article/view/1041

Riyana, C. (2007). Pedoman pengembangan media video. Bandung: Universitas Pendidikan Indonesia.

Sugiyono. (2011). Metode penelitian kuantitatif, kualitatif dan $R \quad \& \quad D$. Bandung: Alfabeta.
Tegeh, I. M., Jampel, I. N., \& Pudjawan, K. (2014). Model penelitian pengembangan. Yogyakarta: Graha Ilmu.

Trianto. (2010). Mendesain model-model pembelajaran inovatif progresif. Jakarta: Kencana Media Pranada Group. 